In the first section of his book, Mr. Farb briefly outlines in layman's language the geological processes which have sculptured the surface of the land. Thence he proceeds to explain the forces that have shaped the coasts of the continent, with intimate accounts of some of the more interesting fauna which inhabit these shores. Similar chapters relating physiography and ecology follow on rivers and waterfalls, on lakes and bogs, on hot springs, geysers and caves, on the mountain systems and on the Great Divide. He is at his best in describing the foreststhe primeval forests of the Great Smoky Mountains, the redwoods and the giant sequoias of the Pacific Coast. Chapters on "The Drylands" deal with the grassland zones, the Colorado Plateau, and the various sections of the Great American Desert, each main part of the Desert having its characteristic indicator plants-the Joshua tree of the Mohave, the saguaro cactus of the Sonoran, the agave of the Chihuahuan and the sagebrush of the Great Basin. A 36-page appendix lists, with descriptive notes, all the national parks and monuments, national forests, wild-life refuges and other sanctuaries in the United States and Canada; and the book concludes with a well-chosen bibliography.

The depredations of man, Indian and European alike, are duly censured; but the picture painted is less gloomy than some depicted elsewhere. One reads that to-day there are more deer, more moose and more song-birds than when Columbus arrived. Thanks to the National Audubon Society, "the American egret, roseate spoonbill, whooping crane, flamingo and half a dozen other notable species have made the long flight back from near-extinetion". "Several decades ago the bison, the elk, the pronghorn, the beaver, the sea otter and many other mammals appeared doomed as species; they are no longer in deep peril to-day."

None of the many excellent illustrations in the volume is in colour-a deficiency which will be deplored by those acquainted with Arizona Highways and comparable travel literature-but this is doubtless unavoidable in a work otherwise handsomely produced at a low cost. To the student proposing to emigrate westward, Mr. Farb's book should be obligatory reading. In those fortunate enough to have toured the North American continent it will evoke many pleasing memories. C. F. DAvidson

\section{INSPIRATION OF THE MIDLANDS}

The Lunar Society of Birmingham

A Social History of Provincial Science and Industry in Eighteenth-Century England. By Robert E. Schofield. Pp. $x+491+12$ plates. (Oxford: Clarendon Press; London: Oxford University Press, 1963.) 70s. net.

R. SCHOFIELD, who has in earlier papers analysed VI the membership of the Lunar Society of Birmingham and the relations between the Society and the Society of Arts, now gives us in this full-scale study of the Society and its members a notable and scholarly contribution to the study of the interactions of science and technology in the late eighteenth century. This is probably the major interest of the book to-day rather than its contribution to the social history of provincial science and industry, which the sub-title suggests. Systematically and thoroughly, Mr. Schofield describes the background in which the Lunar Society arose, the character of the Lunar Circle out of which it was, though still informally, founded, the founding of the Society and its activities in the decade in which it fully flourished, and finally the circumstances which led to its decline and end.

All this is done with a wealth of scholarly detail and precision of reference that must impress the most casual reader with some sense of the immense pains that have gone to the collection of facts so widely scattered, for formal records of the proceedings of this Society do not exist. Much of the material displays the personal qualities and activities of its individual members and their friendsof Small, Wedgwood, Edgeworth, Whitehurst, Watt, Withering, Keir, Boulton, Priestley, Darwin, Day and, finally, Galton, Stokes and Johnson. Here, in so far as it illuminates their relations, the book is fairly described as a contribution on the social history of the times. However, to write this is likely to provoke the comment that there is remarkably little indication of the attitude of manufacturers to the working conditions of their factories, or that, from another angle, we are told too little of Boulton or Wedgwood, for example, as business men. The emphasis is perhaps a little too much on the side of science, insufficiently so on the industrial society.

That seems to be one weakness in the book, for the outstanding feature of the Lunar Society was the way in which it appears to have enlisted the interest of all its members in the discussion and examination of whatever problems were brought to their notice by any one member. At its peak the Society was a remarkable demonstration of the value of discussion by a group of men who could bring to bear on the subject discussed a wide range of outlooks, experience and technique. The Society is of great interest from the point of view of the interaction of science and technology and industry in the late eighteenth century, but in this as in later periods there are still many gaps in our knowledge.

There is one other weakness and that where it might have been hoped the book would make an important contribution. An impressive feature of the Lunar Society is the extent of its links with the Royal Society and with the Society of Arts. Eleven of its members were members of the former and eight of the latter Society: they read papers to them and were able to draw freely on the experience and knowledge to be found among their fellow members. These links are important, and there were other links with local societies-societies which continued long after the Lunar Society ended; for example, the Literary and Philosophical Societies of Manchester and of Newcastle upon Tyne, and the Derby Philosophical Society. Mr. Schofield notes these links, but when in conclusion he discusses "Lunar Descent and Lunar Influence" he has little to add on this aspect, which is far more important than the biographical aspect on which his discussion centres. There are features of the Lunar Society which reappear in the Manchester Literary and Philosophical Society and in the Whalley meetings started by Lyon Playfair about 1843. Both groups included several Fellows of the Royal Society, and some connexion may well exist between the latter meetings and the Chemical Section of the Manchester Society established by the versatile James Young some time after 1839. The exploration of all these links might well be rewarding and throw some light on the development of dyeing and calico printing in the area, and, only a few years later, on the rise of the dyestuffs industry there. Reports prepared for contemporary meetings of the British Association in Manchester and in Newcastle, for example, point to the existence of a lively intermingling of science and technology, with movement from one to the other as well as free discussion.

When all due allowance is made for such shortcomings, this is a welcome and scholarly tribute to a Society the place of which in our industrial and scientific history should not be forgotten. It is a reminder, too, at a time when men are liable to be obsessed with mechanical contrivances in communication and to be separated by over-specialization, of the value of personal contacts and discussion across the different disciplines. The significance of the Lunar Society for innovation and creative advance may well become even clearer if Mr. Schofield's labours induce others to follow his example and patiently strive to fill in some of the further gaps in our knowledge of subsequent interactions of science and technology to which passing reference has here been made.

R. BrightmaN 